\title{
The Establishment Students' Religious Character Through the Distinctive of Madrasah Activities
}

\author{
Ahmad Jamin $^{1}$, Zaini ${ }^{2}$, Suriyadi ${ }^{1}$, Musdizal $^{1}$, Wisnarni ${ }^{1}$ \\ ${ }^{1}$ Institut Agama Islam Negeri Kerinci \\ ${ }^{2}$ Madrasah Aliyah Negeri 1 Sungai Penuh \\ musdizal68@yahoo.com
}

\begin{abstract}
The Distinctive of Madrasah is an extra-curricular activity with Islamic distinctive and character. This distinctive is designed to form the noble character of students based on Islamic values in Madrasah. In the long term, the Distinctive of Madrasah is expected to contribute to preparing fully buman resources as pillars in nation character building. This study aimed to describe the phenomena and experiences of managing the Distinctive of Madrasah activities at MAN I Sungai Penuh as a forum for establishment students' religious character. In this case, the researcher has used a qualitative research design with a phenomenological approach, trying to understand and describe the same experience about the management of the Distinctive of Madrasah activities as a means of establishing students' religious character. The data were collected by observation, interview, and documentation. Then, the informants of this study were the teachers and students at Madrasah Aliyah Negeri 1 Sungai Penuh, which consisted of 11 people. The data were analyzed by reducing, verifying, displaying, and drawing conclusions. The result of this study was the implementation of the Distinctive of Madrasab activities at MAN I Sungai Penuh, which consists of programmed activities, which are scheduled activities, measurable routines, and nonprogrammed activities in the form of daily routine activities, spontaneous and exemplary. Both activities are carried out in an integrated and synergized manner to strengthen the religious character of students. The continuous and continuous implementation of the Distinctive of Madrasah at MAN I Sungai Penuh has brought positive results with the establishment of students' religious character, which is marked by the increased understanding and charity of students' worship and an increased sense of togetherness, brotherhood, and caring among others both in daily life at Madrasah and home.
\end{abstract}

Keywords: Distinctive of Madrasah, Religious Character, Establishment Character of Education

\section{INTRODUCTION}

In Regulation of the Ministry of Religious Affairs, No. 60 of 2015 about Amendments to the Regulation of the Ministry of Religious Affairs No. 90 of 2013 concerning the Implementation of Madrasah Education, article 1 paragraph 2 stated that the Distinctive of Madrasah were all educational activities at Madrasah which have distinctive of Islamic values. The distinctive Madrasah development shaped the Indonesian people as Muslims who were obedient in carrying out their religion. For this purpose, it was necessary to create a conducive and constructive daily atmosphere in the worship life among students, teachers, education staff, and the Madrasah community (Ministry of Religious Affairs, 2016). The development of distinctive Madrasah is based on the mandate of Law No. 20 of 2003 concerning the national education system article 3, which confirms that national education has the function of developing capabilities and forming noble national character 
and civilization to educate the nation's life. Aimed at developing the potential of students to become humans who believe and fear God, have good character, are healthy, knowledgeable, capable, creative, independent, and become democratic and responsible human beings (Directorate General on Islamic Education, 2006).

The distinctive of Madrasah was designed to provide a solid religious foundation, aimed to improve the religious character for students have a strong personality based on Islamic values and become whole Indonesians. More specifically, the development of the distinctive features of Islam aimed a) fulfilling the need for an Islamic learning community at the Madrasah, to produce graduates as moral people who were capable of being religious and became experts in the field of Islam, including skilled personnel in other fields following the demands of national development b) prepared graduates to have the essential abilities needed for self-development as intellectual scholars and c) prepared graduates to carry out education at a higher level (Ministry of Religious Affairs, 2006).

According to the Ministry of Education and Culture (2017), the religious character reflects the faith in God, which was manifested in the behavior of carrying out religious and beliefs, respecting religious differences, upholding tolerant towards the implementation of religious worship and other beliefs, living in harmony and peace between people of different beliefs. Furthermore, the religious character included three dimensions of religious relations: individuals with God, individuals with others, and individuals with the universe (environment). This religious character value was shown in loving behavior and maintaining the integrity of creation (Ministry of Education and Culture, 2017). The values of religious character included respectful attitudes and behavior in implementing the teachings of their religion, being tolerant of the implementation of other religions, and living in harmony with people of other religions, with the first indicator admiring the greatness of God through human ability to synchronize between physical and psychological aspects, secondly admiring the greatness of God because of his ability to live as a member of society and thirdly to admire the power of God (Ministry of Education, 2011).

The implementation of Distinctive of Madrasah was divided into two activities, namely Programmed Habituation Activities and Non-Programmed Habituation activities. Programmed Habituation activities were specially planned and followed by students according to their personal needs and conditions. Programmed self-development activities were carried out with special planning for a certain period in providing for individual student needs, in groups, or classically through guidance and counseling services and extracurricular activities. Meanwhile, Non-programmed Habituation activities were not programmed were habituation activities that included students' character-building activities through routine, spontaneous, and exemplary activities. (Ministry of Religious Affairs, 2006).

Indicators for the implementation of Distinctive of Madrasah were marked by a) an optimal increase in religious education programs, such as through deepening and understanding and additional hours of religious lesson b) created a conducive religious atmosphere that can be seen in daily practice and behavior at Madrasah. c) Increased awareness of glorifying Allah, loving parents, and respecting teachers, as well as doing good 
deeds d) realizing the Syiar of Islam, which was reflected in various religious activities at Madrasah (Ministry of Religious Affairs, 2006)

Education was undoubtedly a powerful tool in realizing intelligent students and character, which was the central pillar of future nation character building to respect the portraits of various character crises in this national life.

Therefore, in encouraged and supported efforts to build the nation's character, the Ministry of National Education in 2010 issued a National Action Plan (NAP) for character education to develop stub projects at the schools throughout Indonesia with 18 character values. In 2017, the government issued Presidential Decree number 87 of 2017 concerning Improving Character Education, known as PPK. This program wants to improve the character building of students, which has been done at many schools and was a continuation of the National Movement for National Character Education in 2010, which was also an integral part of Nawacita. In this case, point 8 of Nawacita mentioned that the revolution of national character and the national movement of mental revolution in education should encourage all stakeholders to make a paradigm shift, namely a change of mindset in managing schools. For this reason, PPK assigned the character values as the most profound dimension of education that civilized education actors (Ministry of Education and Culture, 2017).

The Establishment Character of Education is based on school culture, which focuses on habituation and forming a culture that presents the central values of Establishment Character of Education which were the priorities of the Education unit. This habit was integrated into all activities at school from the atmosphere and a conducive school environment. According to Lickona (2010), character education emphasized the importance of three components of good character: moral knowing, moral feeling, or moral action. According to the Ministry of Education and Culture of the Republic of Indonesia, Establishment Character of Education has goals, including a) developing a national education platform that made the meaning and values of character the main generator of education b) building and equipping the Golden Generation of Indonesia 2045 to face the dynamics of future changes with 21st-century skills and c) restoring character education as spirit and the foundation of education through the harmonization of heart behavior (ethics and spirituality), feeling (aesthetics), thinking (literacy and numeracy), and sports (kinesthetic) (Ministry of Education and Culture, 2017).

Besides, on the micro-level, the character development of students was divided into four pillars: first, intervention and integration into the learning process in each subject in the classroom; secondly, the creation of school culture in the form of habituation in daily life at school; the third was co-curricular and extra-curricular, or self-development activities such as sports, scouting, arts, and religious activities, and the fourth was daily activities at home and in society (Budimansyah, 2012).

Furthermore, implementing the Establishment Character of Education in education units was carried out through three activities. The first intra-curricular activities were learning process activities that were scheduled and systematic based on applicable standards and curriculum and must be followed by every student. Second, co-curricular activities were integrated programs or activities to support the intra-curricular activities, were carried 
out outside of the intra-curricular schedule designed to deepen and enrich learning material in the class and improve skills and aspects of attitudes. Third, extra-curricular activities were skills development activities and improving students' character, which was carried out outside of intra-curricular lessons and co-curricular activities. Extra-curricular activities were designed to develop the interests and talents of students according to the distinctive and interests of students, local wisdom, and available resources (Marzuki, 2019).

It has a relationship with the research that has been conducted by (Mujtahid, 2011) at MTsN 5 in Malang. The resulting research was; to develop Islamic schools or superior Madrasah requires the practical and functional carrying capacity, such as the quality of human resources, infrastructure (representative study rooms, libraries, and laboratories), supporting facilities (boarding/ma'had, mosque, or prayer room). The distinguished Madrasah should be designed according to the vision and mission of institutional objectives, analysis of Academic and Institutional System Requirements, and Understanding Geographical and Cultural Context. Meanwhile, its development requires collective togetherness and mindset, Continuous Innovation, and utilizing Information Technology.

Then the research which has conducted by Azmi (2016) results showed that: (1) the form of religious culture program was carried out through the morning iman and taqwa program, diniyah al-wustha, and takhassus (2) Implementation of character education through religious culture, through Islamic values, Islamic activities, and Islamic symbols (3) implementation of character education through religious culture has an impact on spiritual attitudes, social attitudes, and knowledge.

Furthermore, Rokhayati (2018) has also researched with the result there are religious character values that values instilled are the values of worship, the values of the spirit of jihad, the values of morals and discipline, the values of exemplary, and the values of trust and sincerity. These religious character values are manifested in several activities that are carried out routinely. Namely cultivating smiling, greeting, and shaking hands of the teachers, reading (tadarus) al-Qur'an, reading Asmaul Husna, memorizing short letters of Duha, prayer together with dhuhr prayer in congregation, charity (infaq), praying together (istighasah). reading Yasin, tahlil and ziarah to the founders of the Madrasah. This activity is to instill religious character values at the Madrasah Ibtidaiyah Ma'arif NU 02 Tamansari uses several methods, including methods of advice, Example, rewards and punishments, and habituation.

In response to the national Establishment Character of Education program, MAN 1 Sungai Penuh, one of the Madrasas with a high level of trust from the community, has launched a flagship program, namely CIKAMAD (the Madrasah Distinctive Activities), known as Madrasah Specific Activities. Distinctive of Madrasah at MAN 1 Sungai Penuh were patterned in the form of programmed and non-programmed, and consistent habituation activities have had a positive impact on the religious character of students. Indicators of success were reflected in the increased ability of recitation of the Qur'an, memorization of verses and letters, understanding and obedience in worship, more skill in leading prayers, and dhikr. 
Based on the background of the problem above, this research was aimed to describe the management strategy Distinctive of Madrasah at MAN I Sungai Penuh as a forum for improving the religious character of students.

\section{METHOD}

The approach used in this study was qualitative (Bogdan \& Biklen, 1992). This study used a phenomenological study approach (Creswell, 2013), which described the phenomena and experiences of several individuals (participants) in organizing Distinctive of Madrasah at MAN 1 Sungai Penuh. Key informants were the Distinctive of Madrasah supervisor, and supporting informants were the Head of Madrasah and students. The students were selected using the purposive sampling technique. Data were collected through observation, open interviews, and documentation, with observation sheet instruments, interview, and documentation guidelines. The data collected, then analyzed by data reduction stages, data display, and concluding (Huberman, Miles, Denzin, \& Lincoln, 1994).

\section{FINDINGS}

\section{Implementation of Madrasah Specific Activities}

The implementation of Distinctive of Madrasah at MAN I Sungai Penuh refers to the guidelines from the Ministry of Religion, which were divided into two activities: First, Programmed Habituation activities and Non-programmed Habituation activities. Programmed Habituation activities were specially planned and followed by students according to their personal needs and conditions. Programmed self-development activities were carried out with special planning for a certain period to provide the needs of students individually, in groups, or classically through the provision of guidance and counseling services and extra-curricular activities. Second, non-programmed habituation activities were habituation activities that included activities that were character building for students, which were carried out through routine, spontaneous and exemplary activities.

The Head of Madrasah explained about Programmed Habituation activities:

We have made specific plans, schedules, and measurable targets. Programmed Habituation activities were carried out face to face every Friday afternoon from 15.15 to 16.45, with the material of tabfidz juz. 'Amma, tahfidz of surah Yasin, ar-Rahman, and as-Sajdah, AlQur'an Recitation Training, Worship Practice Training, Memorization of Prayers (14 verses) and Recitation (11 verses), Memorizing Thematic Prayers (15 themes). Besides, the Non-programmed Habituation activities were carried out separated from learning class, such as Tadarrus the al-Qur'an, praying before and after learning class, Zubr prayers in the congregation, Tausyiah, Spreading Greetings, Friday Infaq, Social Visits, Celebration of Islamic Holiday, and Islamic Boarding School for Ramadhan.

Furthermore, the Head of Madrasah also explained: According to the implementation of tabfidz juz.'Amma, Surah Yasin, Surah ar-Rahman, Surah as-Sajdah, and recitation training, we want this activity as a forum for students to increase their love and understanding of the Qu'ran. The purposes were: first, the students can memorize juz 'amma (37 surahs), surah Yasin, ar-Rahman, and as-Sajadah. Second, the increase in recitations' quality included aspects of tajwid, fashahah, and songs. Then, 
related to the practice of praying, besides the students receiving guidance in worship class, we also obliged the students to pray dhubr in congregational at the mosque. In addition, with this activity, the religious atmosphere of the students at the Madrasah increased, and the students became educated to carry out prayers correctly and adequately, both in the Madrasah environment and in the community. Furthermore, we also hope that students are brave and able to become prayer leaders. Moreover, the most important thing was the increasing obedience of students in worship.

Based on the explanation of the Head of the Madrasah, the first supervisor of

Distinctive of Madrasah stated:

In order to the activities of tabfidz juz.'Amma, Surat Yasin, Surat ar-Rabman, Surat As-Sajdah, and recitation training, we as guides to improve the religious character of students. These activities namely by giving assignments to students for each face-to-face meeting, each student was required to provide the memorization deposit in front ofstudentervisor, sometimes we listen to the students' rote reading, and sometimes we read it, and the students connect it. Furthermore, the target that we wanted from this activity was that students could complete their memorization up to the semester exams for teenth-grade (18 surahs), XI-grade (25 surahs), and XII-grade (37 surahs).

Relevance with the recitation of the Qur'an and the practice of worship, the second supervisor of Distinctive of Madrasah stated:

For the implementation, sometimes we practice reading the Qur'an immediately in front of the students, and sometimes students practice it while we justify their reading. The target that we want the students to be able to read al-Qur'an fluently, so it will make the students feel loved to the Al-Qur'an. The practice of worship was carried out independently, which means to know and measure how far the students' knowledge and skill in worship practice. This activity was facilitated or guided by a supervisor following the task who was guided. Furthermore, it is also carried out collectively by appointing students in turn to become priests and congregations. This activity aimed to make the students be priests and congregation in prayer because we also practice praying masbuk. In order to implementation of our worship practices, we were carried out independently. This form of activity was intended to know and measure the extent to which students were mastery in their worship practices of theory. We guided the students, in turn, to read the funeral prayer readings from niat until salam. Moreover, for practice, we bring the students to the mosque using the PAI props at MAN 1 Sungai Penuh.

The first student confirmed the statement above, he stated:

For the activities of tabfir juz amma, Surah Yasin, ar-Rahman, and as-Sajadah, we were given the task of depositing memorized verses in front of the supervisor. Furthermore, we were also given the task of each meeting to have additional verse deposits. Moreover, we were given a rote guideline to remember the words at the beginning of the verse, making it easier to memorize. This activity was very beneficial for us. Furthermore, my target was with this guidance. I can memorize surah Yasin, ar-Rahman, and as-Sajadah. Related to the process of recitation activity, we were given guidance in reading the Qur'an with recitation and listening to the teacher's reading, and sometimes we were instructed to read it one by one and sometimes together. Furthermore, we also have additional assignments to study a lot at bome. 
The statement above was also supported by the second student who stated:

To implement our worship practice, starting from the niat to salam, praying in the congregation, such as the procedures if we were a masbuk and a traveler's prayer. Related to memorizing prayers at MAN 1 Sungai Penuh, we were given the task by the supervisor to memorize each meeting, and we were required to memorize the prayer that has been set at MAN 1 Sungai Penub because memorizing prayer was a requirement for semester exams. We feel we have the responsibility to memorize it. For memorizing thematic prayers, we were given the task to memorize thematic prayers, such as learning prayer, leaving the house, entering the mosque, and others related to daily activities in praying. We were given the task of memorizing at least 15 themes and recording them in a unique book of Distinctive of Madrasah, and each of us was obliged to have a prayer notebook.

Furthermore, for the implementation of Non-programmed Habituation activities, the head of Madrasah stated that:

Non-programmed habituation activities consisted of Tadarrus al-Qur'an, praying before and after learning class, Zubr prayers in congregation, Tausyiah, Friday Infaq, Social Visits, Celebrating Islamic Holidays, And the Islamic Boarding School for Ramadan. Read Al-Qur'an for 15 minutes every Tuesday till Friday morning in the classroom with monitoring by the tutor of each class. Reading Al-Qur'an in the mosque by each class representative as many as five people, and Reading Al-Qur'an collectively in the field once a month on Friday.

Furthermore, the Coordinator of Distinctive of Madrasah stated that

daily activities of praying and praying Zubr in the congregation aimed to memorize prayers and habituate congregational prayers in the mosques. For Zubr prayer in congregation, it was carried out in the mosque every Monday to Saturday except Friday, and this activity was carried out in 3 stages, starting from class X, then class XI, and finally class XII, each student was scheduled as Azan and prayer officer, and this was carried out in turns for each class. This activity aimed to train the students to worship at MAN 1 Sungai Penuh and outside the Madrasah environment. This activity involved a guiding teacher as an Imam for Zubr prayer in congregation with the students at the mosque. Related to the babit of spreading greetings, we always remind the students that they do not say greetings if they meet a teacher. We gave them understanding. The implementation of greetings habituation aimed to instill students' respect for teachers and their friends in their daily life at the Madrasah, so these students' habits can be a habit with their parents at home and in the community.

Then, the third student added the following:

Every morning before studying and after learning ended, we were given an assignment. Each class read the prayers that have been determined by the Madrasah Distinctive coach that has been conceptualized. Generally, we have memorized all of these prayers, and we carry out this prayer activity regularly".

To Friday's infaq activities and Celebrating of Islamic Holiday, based on an interview with the third supervisor of Distinctive of Madrasah stated that: 
Infaq was held every Friday to belp if any of the teachers or students got a disaster. It was done on Friday after Tadarrus activities in the field and Madrasah development activities from the Distinctive of Madrasahsupervisor. To improve the students' religious values, in every Islamic holiday activity apart from inviting outside speakers to listen to Tausyiah from ustad\%. In this event, we presented various religious activities that aimed to develop knowledge, skills, and religious attitudes of students including, kultum, appearance Asma'ul Husna, syarbil Quran, and finally a quiz, with prizes for students and this was carried out regularly when there was an activity to celebrate the Islamic holidays.

\section{Strategies for Improving the Religious Character of Students}

For the effectiveness of achieving the goals of Madrasah Specific Activities, especially in improving the religious character of students, Distinctive of Madrasah managers applied strategies and methods including guidance regularly on Fridays, given the rewards and punishments, and conducted Distinctive of Madrasah evaluations.

\section{Provided Regular Guidance}

To make students reflect religious behavior, supervisors of Distinctive Madrasah regularly carry out the guidance in the field on Friday. Each student followed this activity for each class, with the kinds of activities: first, given motivation and advice for students always to add memorizing verses, improve the memorization of prayers, and others related to Distinctive of Madrasah programmed non-programmed habituation.

\section{Created an Open Forum}

We have created an open forum to display and promote students' achievements in front of supervisors and other students such as memorizing juz' 'Amma, Yasin, ar-Rahman, as-Sajdah.

Related to the above, in the context of improving the religious character of students, the first supervisor of Madrasah Specific Activities stated that:

Concerning Madrasah development, it was carried out every Friday; we spent about 30 minutes reminding and inviting the children to participate in Distinctive of Madrasah that has been programmed at the Madrasah and applied the good habits at the Madrasah. As guides, we always remind the students whom we guide to be active in Madrasah Specific Activities, such as improving the memorization of verses, prayers, and remembrance of carrying out the recitation of the Qur'an, praying dhubr in the congregation, spreading greetings, giving donations and other activities programmed in Madrasab Specific Activities.

To advise the religious character of students, the fourth student stated:

It was true that every Saturday, before studying at the first lesson of the morning, we gathered in the field to do gymnastics. After that, we were given tausyiah in the form of coaching. With this coaching activity, we were motivated to always be active in Madrasah Specific Activities, as well as the activity supervisors constantly reminded us to be active in these activities and did the assigned tasks. 


\section{Provided Rewards and Punishment.}

For students who were excellent in Madrasah Specific Activities, the rewards were given in several categories, namely (1) Rating for the first winner of each class, (2) Ratting for the runner up of each class, (3) Giving Tabanas in cash for the first winner and runner up of each class, and (4) Giving the certificate for the winners in the field of Madrasah Specific Activities.

In this case, the second supervisor of Distinctive of Madrasah stated that:

To improve the religious character of students, the students who are excellent in the field of Distinctive of Madrasabwere given prizes in the form of money and certificates from Madrasah for their achievements in the field of Madrasah Specific Activities. The targets we want with these rewards will be improving the students' motivation and religious attitudes. Besides, to improve students' activities, religious activities at the Madrasah, especially in this Madrasah Specific Activities, we announced the students who were excellent from the first winner through runner up every final semester as the rewards for their work.

While the punishment was given to students who were disobedient and did not fulfill the achievement of activities, the forms of punishment were given by the second supervisor of Madrasah Specific Activities: first, giving the additional assignments in the form of specific guidance from supervisors of Madrasah Specific Activities, second, inviting parents for students who have the problems in Madrasah Specific Activities, such as not reach the achievement of minimum competency scores in the material of Distinctive of Madrasah, and third, being considered did not go up a class with coaching for one month.

\section{Doing an Activity Evaluation}

To improve the religious character of students in Madrasah, conduct Specific Activities strategies were applied to evaluate all student activities in each Madrasah Specific Activities, namely conducting an assessment at the end of each semester in the form of a Distinctive of Madrasah verification exam.

Based on the results of an interview with the Head of MAN 1 Sungai Penuh, stated that:

Concerning the evaluation of Distinctive of Madrasahcarried out every last semester with the evaluation of Madrasah Specific Activities, it was hoped that students were motivated to 
be active and have a sense of responsibility in carrying out what has been programmed in each Madrasah Specific Activities.

Related to what has been described by the Head of MAN 1 Sungai Penuh above, the third supervisor of Distinctive of Madrasah stated:

In the context of improving the religious character of our students, we carried out two forms of assessment in the form of oral tests, such as memorizing verses, memorizing prayers and dhikr, and practicing moderate worship for assessments such as Zubr prayer activities in the congregation. It was also reading Holly Al-Quran, Friday infaq, and others that have good moral habituation we carried out in the form of assessment through student attendance control in Distinctive of Madrasahand monitoring every student activity.

\section{Achievements of the Distinctive of Madrasah}

The success of improving the religious character of students through Madrasah Specific Activities, which were integrated into Programmed and Non-programmed Habituation activities, has brought positive results for the establishment and improvement of the religious character of students with the indicators, as follows:

\section{Increasing the Quality of Reading the Qur'an}

The success of the implementation of Al-Quran recitation training activities can be seen from the students' ability to recite Al-Qur'an based on tajwid.

The second supervisor of Distinctive of Madrasah stated:

In our opinion, the condition of the students' religious character was good. We can be seen that the students' ability to read the Qur'an increased after the guidance activities in general. There were no students who could not read the Qur'an, many students whose has been good at reciting the Qur'an based on tajwid.

The statement above was emphasized by the fifth student, who stated:

By the guidance of the recitation of the Qur'an, this was very beneficial for us, and Alhamdulillah I feel there was an increase in recited it, especially the tajwid. Judging from the results of the final verification contained in my Distinctive of Madrasabreport card, I got good grades in Reciting the Al-Qur'an.

Increasing the Ability of Students to Memorize the Verses of the Qur'an

Distinctive of Madrasah were very useful for improving memorization/tahfidz of students, the sixth students stated:

By the activities of tabfid juz 'amma, Yasin, and ar-Rahman, it was very beneficial for us, we were motivated to want to memorize the verses of the Al-Qur'an, and we feel we have the responsibility to carry out the tasks given by the supervisor such as adding memorization and improved the memorization of verses. The results of the final verification of Madrasah Specific Activities, showing a good increase in religious students. Generally, many students of MAN 1 Sungai Penub have memorized juz 'amma, Yasin, ar-Rahman, 
and as-Sajadah, so I think there was an increase in the conditions of the religious character of students in studying the Qur'an and memorizing the Qur'an.

Increasing the Students' Understanding and Deeds of Worship

According to the second supervisor of Madrasah Specific Activities, based on the results of routine evaluation of activities where data was obtained:

Implementing practical Worship training activities will increase the students' understanding of the problems in worship, both fardhu prayer, sunnah prayer, and congregational prayer, besides increasing their awareness and discipline in the practice of prayer, such as the discipline to pray in congregation both at school and at home. These activities can be seen from the results of the final verification contained in the report card of Madrasah Specific Activities; the students have fulfilled competency achievements with good grades.

The Students have Good Skills in Leading Prayer and Dhikr.

Generally, the student's ability and skills in praying both in prayer and dhikr, both individually and in the congregation, have increased, this can be seen from the results of the final verification contained in the report card of Madrasah Specific Activities, the students have fulfilled competency achievements with excellent grades.

The first supervisor of Distinctive of Madrasah stated as follows:

By the practice of prayer and remembrance dhikr and memorizing thematic prayers of students, it has a positive impact on improving the religious character of students; it can be seen that there were positive changes to the students before the training. Generally, the students did not memorize the prayers and dhikr, but there was a good increase in the guided students after the training where the students can lead prayers and dhiker after prayer.

Besides the achievements of programmed activities above, the crucial achievements in improving the religious character of students were also obtained through nonprogrammed activities with the indicators as stated by the first supervisor of Madrasah Specific Activities, namely a) Increased intensity or routine of students in reciting the Qur'an b) the realization of a religious atmosphere that was conducive to students in worship c) The development of positive behavior of students in respecting teachers, parents and others d) increasing the character of social care and happy giving e) increasing the friendship each student and f) increasing the number of Islamic syiar in the Madrasah environment.

\section{DISCUSSION}

The implementation of Distinctive of Madrasah at MAN I Sungai Penuh was an additional or extra-curricular activity aimed at improving the religious character of students at the Madrasah environment, at home, and in the community. They were improving the character of students based on Madrasah culture focused on the habituation process through extra-curricular activities and daily activities at the Madrasah based on the principal 
values. The Distinctive of Madrasah program following the Master Character Education Design (Kartadinta, 2010) where on a micro level, the development of values/character through extra-curricular activities in the form of culture and habituation (Madrasah culture) in daily activities at the Madrasah environment and the community was an essential pillar besides to learning activities in the classroom.

The establishment of character education was the priority of the education unit. This habituation was integrated into all activities and was reflected in the atmosphere and conducive school environment. According to Marzuki (2019), forming a noble moral culture means developing traditions or habits in a place, namely moral values. The character building of students means an effort to familiarize the character of students through various activities, both inside and outside of Madrasah (Ministry of Education and Culture, 2017).

The implementation of Distinctive of Madrasah at MAN 1 Sungai Penuh based on an interview with the headmaster and some teachers as the informant were: integrated and synergizes between programmed activities which include tahfidz activities, al-Quran recitation, worship practices, memorizing prayers and dhikr, and non-programmed activities regularly, spontaneous and exemplary activities, in the process integrated into the activities of students in the form of recitation of the Al-Qur'an every morning, praying before and after learning, spreading greetings, Tausyiah, Friday infaq, social visits, the celebration of Islamic holidays and Islamic boarding schools for Ramadhan.

The strategies applied in improving students' religious character in this study are routine guidance, rewards and punishments, and objective and accountable judgments. The development of religious character in Madrasah was related to the development of Madrasah culture to achieve optimal results in developing an excellent moral culture at Madrasah. Experts argued that in the context of character building at Madrasah, there were several methods in character education, including through advice and giving special attention to the students in the context of character building. This method was beneficial in motivating students to commit to the rules or good moral values that must be applied. Giving rewards as an incentive to students, motivated to do good things or have a religious character, and punishment as a deterrent effect for students, so they do not dare to do bad things (have evil characters) or defied the rules (Marzuki, 2019).

Besides, Fatihin (2018) has conducted research entitled Implementation of Students' Character Education through Religious Activities at Madrasah Tsanawiyah Negeri Wonosegoro Boyolali Regency. The study results indicate that the implementation of student character education through religious activities has been going well following the predetermined program through several activities, both habituation, intra-school and extracurricular activities. Habituation activities include listening and memorizing Juz amma, praying dhuha in the congregation, praying before class, reading Asmaul Husna, infaq, and praying dzuhur in the congregation. Religious activities through intra-school are religious learning activities carried out in class, and religious activities carried out through extracurricular activities, namely tahfidz or memorizing the Qur'an and calligraphy. The character values instilled through these religious activities are religion, discipline, responsibility, honesty, love of reading, social care, hard work, communication, tolerance, 
and respect for achievement. The instilled character values are religion, discipline, responsibility, honesty, love of reading, social care, hard work, communication, tolerance, and respect for achievement. The obstacles faced are the limited time for religious activities, inadequate facilities, less than optimal supervision of activities, and lack of enthusiasm for participating in religious activities. The way to overcome the problem is to add hours of activities outside of teaching and learning activities. The implementation of midday prayer activities is divided into two places, namely the mosque and the prayer room. Make a schedule for the dhuha prayer in turns, and make a list of attendance.

Thus, from the finding of this research, it could be said that, in improving the religious character of students, Distinctive of Madrasah were following the roles and principles of developing Madrasah culture, such as: first, schools or educational institutions should be able to shape students to be a success in academic and non-academic. As for non-democratic values concerning attitudes and behavior (good morals) so that graduates were not only intelligent in mind but also emotionally and spiritually intelligent, and secondly, for the development of noble culture and character in schools, a school program was needed that explicitly and in detail to support the realization of this culture. This program was designed for the development or habituation of daily students, both in the practice of religious teachings and moral values (Marzuki, 2019).

\section{CONCLUSION}

The implementation of Distinctive of Madrasah to improve the religious character of students goes well. These activities were integrated into the form of activities: Recitation of the Qur'an, Tahfidz Juz' Amma, Surah Yasin, ar-Rahman and as-Sajdah, Worship Practices, and memorization of prayers and dhikr and b) non-programmed habituation activities, namely the habituation of the good morals of students in their daily lives at Madrasah, through routine, spontaneous and exemplary activities. Such as the recitation of the Qur'an every morning, prayer before and after teaching and learning activities, Zuhr prayer in congregation, Absussalam, Friday Infaq, Tausyiah, Social Visits, and Islamic boarding schools for Ramadhan.

The success of improving the religious character of students through Distinctive of Madrasah at MAN I Sungai Penuh, integrated into programmed and non-programmed habituation activities in the form of routine, spontaneous and exemplary activities, have brought good results. In contrast, the results of improving the religious character of students have been achieved well. Where the students were able to read the Qur'an correctly and adequately according to recitation, increase the number of students memorizing verses, the students have good skills in worship, the students were skilled in practicing prayer and zikr. Routine and intensity of recitation of the Qur'an of students increases create a good religious atmosphere for students in worship, the realization of positive behavior of students in respecting parents, teachers, and fellow students, the realization of positive behavior likes happy giving, build up the friendship between teachers. 


\section{REFERENCES}

Azmi, M. U. (2016). Implementasi Pendidikan Karakter Melalui Budaya Religius Di Madrasah Tsanawiyah Mu'allimin Nabdlatul Wathan Pancor Lombok Timur. (Doctoral dissertation, Universitas Islam Negeri Maulana Malik Ibrahim). http://etheses.uinmalang.ac.id/10222/1/13771004.pdf

Budimansyah. (2012). Dimensi-Dimensi Praktek Pendidikan Karakter. Bandung: Widya Aksara Press.

Bogdan, R. C., \& Biklen, S. K. (1992). Bogdan, Robert C., and Sari Knopp Biklen, Qualitative Research for Education: An Introduction to Theory and Methods, 2d Ed. Boston: Allyn \& Bacon, 1992.

Creswell, J. W. (2015). Qualitative inquiry \& research design: Choosing among five approaches. (Lazuardi, Trans.). Yogyakarta: Pustaka Pelajar.

Departemen Agama RI. (2006). Al - Qur'an dan Terjemahannya. Jakarta: Maghfirah Pustaka.

Departemen Agama RI. (2018). Bina Mitra Pemberdayaan Madrasah Standar Operasional Ciri Khas Madrasah. Jakarta: Bina Mitra Pemberdayaan Madrasah.

Departemen Pendidikan Nasional, (2018). Kamus Besar Bahasa Indonesia Pusat Bahasa, Jakarta: PT Gramedia Pustaka Utama

Fatihin, K. (2018). Implementasi Pendidikan Karakter Siswa melalui Kegiatan Keagamaan di Madrasah Tsanawiyah Negeri Wonosegoro Kab. Boyolali Tahun Pelajaran 2017/2018 (Doctoral dissertation, IAIN Salatiga).

Huberman, A. M., Miles, M. B., Denzin, N. K., \& Lincoln, Y. S. (1994). Handbook of qualitative research. Data management and analysis methods. Thousand Oaks, CA, Sage, 428-444.

Jamin, A. (2014). Filsafat Pendidikan Islam: Aktualisasi nilai-nilai Islam dalam Mewujudkan SDM yang Berkrakter. Bandung: Alfabeta.

Kartadinata. (2010). Mendidik Untuk Membentuk Karakter. Terjemahan Uyu Wahyudi. Jakarta: Bumi Aksara.

Kementerian Agama RI. (2013). Peraturan Menteri Agama RI Tentang Penyelenggaraan Pendidikan Madrasah. https : //e dokumen. Ke Menag. Go.id. PMA- No 60 Tahun 2005. Perubahan atas PMA No 90 tahun 2013.

Kemendikbud RI. (2017). Konsep Dan Pedoman Penguatan Pendidikan Karakter. Jakarta: TIM Penguatan Pendidikan Karakter

Kementerian Pendidikan Nasional. (2011). Pedoman Pelaksanaan Pendidikan Karakter (Berdasarkan Pengalaman Di Satuan Pendidikan Rintisan). Jakarta: Kemendiknas 
Lickona, T. (2010). Educating for Character (Mendidik Untuk Memberntuk Karakter). Jakarta: Bumi Aksara.

Marzuki. (2019). Pendidikan Karakter Islam. Jakarta: Amzah

Mujtahid, M. (2011). Pengembangan Madrasah dan Sekolah Islam Unggulan. el-hikmah, (1).

Rokhayati, S. (2018). Penanaman Nilai Karakter Religius Di Madrasab Ibtidaiyah Ma'arif Nu 02 Tamansari Karangmoncol Purbalingga. (Doctoral dissertation, IAIN Purwokerto). http://repository.iainpurwokerto.ac.id/4072/1/COVER BAB\%20I BAB\%20V D AFTAR $\% 20$ PUSTAKA.pdf

Undang-undang RI Nomor 20 Tahun 2003 tentang Sistem Pendidikan Nasional dalam Undang-undang dan Undang-undang Pemerintah RI tentang Pendidikan, Jakarta: Ditjen Pendidikan Islam, 2006

\section{AUTHORS CONTRIBUTION}

\begin{tabular}{|l|l|}
\hline \multicolumn{1}{|c|}{ Author } & \multicolumn{1}{c|}{ Contribution } \\
\hline Ahmad Jamin & $\begin{array}{l}\text { Provide writing ideas, writing guidance, and complete } \\
\text { the writing of the article }\end{array}$ \\
\hline Zaini & $\begin{array}{l}\text { Complete the writing of the article } \\
\text { Suriyadi } \\
\text { Check, improve and proofread the contents of the } \\
\text { article }\end{array}$ \\
\hline Musdizal & $\begin{array}{l}\text { Corresponding Author. Translate, check grammar and } \\
\text { revise the article }\end{array}$ \\
\hline Wisnarni & \begin{tabular}{l} 
Complete data collection and analysis \\
\hline
\end{tabular} \\
\hline
\end{tabular}

